\title{
AN INTRODUCTION TO THE POLITICS OF PARTY ALLIANCES AND COALITIONS IN SOCIALLY-DIVIDED AFRICA
}

\author{
Denis Kadima \\ Denis Kadima is Executive Director of the Electoral Institute for \\ Sustainable Democracy in Africa (EISA) \\ e-mail: dkadima@eisa.org.za
}

\begin{abstract}
There is a gradual emergence of a body of knowledge about the factors that stimulate the formation, survival and disintegration of party alliances and coalitions in Africa. What is relatively less known is the impact of these alliances and coalitions on various aspects of political and governance systems in African countries. This article is a modest step towards explaining the effects of party alliances and coalitions on national cohesion and party systems in Africa's socially-divided states.
\end{abstract}

\section{INTRODUCTION}

Pre-electoral alliances and post-election coalitions of political parties have become an increasingly significant feature of contemporary African politics. A study of this political phenomenon is important to an understanding of election dynamics and government formation politics in Africa. It is encouraging to note that in the past decade there has been a relative increase in studies devoted to alliances and coalitions in Africa (Karume 2003; Sithanen 2003; Kadima 2003, 2006a; Kapa 2008; Resnick 2011; Arriola 2013). In spite of this increase, various aspects of this political phenomenon are still largely under studied. The majority of studies look at the causes of alliances and coalitions (Karume 2003; Kapa 2008) and only a few have tried to explain the effects on the political, party and democratic systems of African countries (Resnick 2011; Kadima 2006b). On the other hand, coalition theories have their roots mainly in the experiences of Western European countries and therefore tend to focus excessively on post-election coalitions. Yet, in Africa, pre-electoral alliances occur nearly as frequently as post-election coalitions.

A study of the number of African countries with pre-electoral alliances and / or coalition governments (as opposed to single-party governments) in the period up to October 2013 is quite revealing. When one excludes countries in which 
multiparty parliamentary elections have not been held for a variety of reasons (Eritrea, Sahrawi, Somalia and Swaziland), pre-election party alliances were formed in the most recent legislative elections in 51\% of African states and 54.9\% had some form of coalition government. Similarly, pre-election alliances were formed for presidential elections in the same period in 22 of 43 countries (51.2\%), excluding monarchies (Lesotho, Morocco and Swaziland), indirectly elected presidents (Botswana, Ethiopia, Libya, Mauritius, South Africa and Tunisia) and countries that did not hold (presidential) elections (Eritrea, Sahrawi and Somalia).

This introductory article develops the insights and arguments originally posited in early work on African Party Alliances (Kadima 2006b). It is a modest step towards not only explaining the causes and factors stimulating the formation, survival and disintegration of party alliances and coalitions in Africa's sociallydivided states but also the consequences of these alliances and coalitions for national cohesion and party systems.

It is worth starting this study by defining a number of concepts, namely 'alliance', 'coalition', 'party system' and 'national cohesion'. Given their similarities as inter-party cooperation modalities the terms alliance and coalition are generally used interchangeably. However, owing to the unique features of the platforms and processes characterising alliances and coalitions it would be useful to differentiate between the terms. Andrew Wyatt (1999) argues that

in forming coalitions, politicians leading disciplined parties have a clear idea of their respective strengths whereas politicians forming electoral alliances work with less certainty as they only have an estimate of the strength of their electoral support and how it might be affected by a potential alliance. Likewise they can only estimate the electoral cost of an ideologically-inconsistent alliance.

What is implicit in this distinction between an alliance and a coalition is that the former is formed before an election and the latter is built on the basis of the election outcome.

Based on Wyatt's characterisation, 'alliance' can be defined as the coming together of at least two political parties prior to an election in order to maximise their votes, while a 'coalition' refers to the agreement of a minimum of two political parties to work together in Parliament and/or in government on the basis of the election outcome. Both alliances and coalitions are characterised by the coming together of a minimum of two political parties for a certain period, in pursuit of an agreed set of common goals to be reached by means of a common strategy, joint actions, the pooling of resources and the distribution of possible subsequent pay-offs (2006b). 
It is also useful to define the notions of 'party system' and 'national cohesion', two important parameters analysed in this article. Party system refers to 'the way in which various parties interact at a particular level of political competition and/or cooperation (eg, predominant party system, multiparty system, etc)' (Lefebvre \& Robin, 2009). The differentiation between party systems in various countries and within the same country is generally based on the variance in terms of competitiveness, cooperation, stability and fragmentation. As for national cohesion, it is the process of constructing a nation by using state power with the aim of unifying the various communal groups within the state and ensuring political cohesion and stability, social harmony and a sense of common (desired) destiny.

Eghosa Osaghae (1999) uses the term 'to refer to a process of constructing a weness or a sense of belonging among members of different groups in a polity, through the regulation and reconciliation of differences as well as competing interests and demands'. In a cohesive state there may be ethnic, racial and religious differences but they are of secondary importance in determining political behaviour. A key variable is the degree to which political parties politicise ethnicity and other subnational segmentary identities.

This study, although primarily based on the experiences of Kenya, Malawi, Mauritius, Mozambique and South Africa, also draws on evidence from other African countries to explain the patterns of party alliance and coalition politics in Africa and assesses the extent to which coalition theories, mostly derived from the analysis of government-building in Western European countries, can form a compelling explanatory framework for the formation and collapse of electoral alliance and coalition politics on the continent. The five countries studied were chosen on the basis of four main criteria:

- A history of pre-electoral alliances and post-election coalitions;

- A mix of political regimes: presidential (Kenya and Malawi) and parliamentary (Mauritius and South Africa);

- A mix of electoral systems: proportional representation (South Africa and Mozambique) and plurality (Kenya, Malawi and Mauritius); and

- A mix of party systems: dominant (South Africa and Mozambique), two-party (Mauritius) and multiparty (Kenya and Malawi).

The study addresses three main questions: What are the causes and factors motivating alliance and coalition building? How effective have electoral alliances and coalition governments been in fostering national cohesion in socially-divided African countries? What has been the impact of party alliances and coalitions on party systems in Africa? 
The article is divided into four sections, excluding this introduction and the conclusion. These are: a brief review of coalition theories; the background to party alliances and coalitions in Africa; the causes and factors motivating alliance- and coalition-building, survival and disintegration and the effects of party alliances and coalitions on political systems and party systems in Africa.

\section{COALITION THEORIES}

'What is the applicability to African contexts of theories of party alliances and coalitions developed in other settings and, if relevant, in what ways might they need modification?' This is the guiding question in this section. The theories of party coalitions are essentially based on the experiences of continental Western Europe (Gamson 1961; Riker 1962; Axelrod 1970; De Swaan 1973; Dodd 1976; Luebbert 1983). These theories have focused on predicting and explaining models of government formation and termination in parliamentary democracies. Two main approaches are used in studying the subject, namely the theories of size and ideology, on the one hand, and the new institutionalist theory, on the other.

Theories of coalition based on size and ideology emerged in the 1960s and 1970s. They centre on the effects of a potential coalition's size and ideology on its chances of formation and may be subdivided into office-seeking and policyseeking theories. Office-seeking theories are based on the assumption that the main goal of political parties is to access power. For the defenders of this viewpoint, government formation is a win-lose scenario in which Cabinet portfolios are the payoffs. Therefore, if the most important thing for political parties is to receive Cabinet portfolios, a majority coalition in Parliament would not accept the existence of a minority government and would take the spoils of office for itself.

These theories have gradually been refined. The minimal winning hypothesis was applied to government formation by William Gamson (1961) and was later ameliorated by William Riker (1962). The theory is based on the assumption that government coalitions should comprise as few political parties as possible - just enough to win the legislature's vote of confidence. Minimal winning governments, therefore, in order to maximise possible office benefits, carry no passengers. Michael Leiserson (1968) also supported the minimum winning theory, arguing that the prospective government should seek to minimise the number of political parties in the coalition because it is easier for a smaller group of parties to reach consensus.

It is undeniable that the core arguments of office-seeking theories are relevant in African contexts. The main reason for the formation of alliances and coalitions in Africa, as elsewhere, is to hold public office. However, the argument that minimal winning governments carrying no passengers are most likely to be formed in 
order to maximise possible office benefits is often contradicted in African contexts where pre-electoral alliances rather than post-election coalitions tend to be made as large as possible deliberately in order to guarantee electoral victory even if this means not maximising the benefits.

The assumption on which policy-seeking theories are based is that party coalitions are justified by policy goals. Robert Axelrod (1970) suggests that officeseeking coalitions pursue the maximisation of their benefits while minimising the coalition's bargaining costs by forming only those winning coalitions that contain ideologically adjacent parties; hence the hypothesis of minimal connected winning coalitions. Similarly, Abram De Swaan (1973) notes that political parties form the minimal winning coalition with the smallest ideological range, which positions the hypothesis of 'ideologically compact winning coalitions'. Concurring with Axelrod's and De Swaan's views, Paul Warwick (1994) argues that ideologically diverse governments tend not to survive because of the greater policy compromises coalition members have to make.

Policy-seeking theories are sound, but they do not appear to be a solid basis for adequately explaining alliance and coalition building and collapse in most African countries. This is because the differentiation between political parties from an ideological or policy standpoint is not rigid. The end of the Cold War has seen a shift by the main parties towards the centre. Even in those few countries with relatively more delineated ideologies (eg, Mauritius and South Africa) high poverty levels have forced party leaders to grant the state a comparatively large role in the market economy in order to fast-track national socio-economic development. This convergence of the main priorities creates a degree of connection among the majority of mainstream political parties, thus justifying why most parties can compatibly share power. Divisions tend to be, in essence, personality-driven rather than ideologically based.

Finally, coalition theories emerging from the study of party coalitions in Western Europe do not account sufficiently in their theorisation for socialcleavage-related factors. Most scholars argue that social cleavages such as race, religion, class and gender have declined in political importance throughout the mature democracies (Hamilton 1972; Dalton and Wattenberg 1993; Franklin 1985 and 1992 and Lawrence 1996). However, other scholars of party coalitions in advanced democracies disagree. Jeff Manza and Clem Brooks (2003) believe that 'despite significant changes in the American political landscape, social cleavages as a whole remain an important source of voter alignments and the composition of the Democratic and Republican Party coalitions'.

This study pays particular attention to the weight of the social cleavage dimension in party alliances and coalitions in Africa. The experiences of countries such as India offer useful insights. Explaining why an alliance between the Bahujan 
Samaj Party (BSP) and the Samajwadi Party (SP) in the electorally vital state of Uttar Pradesh during the 1998 legislative elections, which would have prevented the Bharatiya Janata Party (BJP) from coming to power, did not form, Andrew Wyatt argues that deep social cleavages partly made the negotiations difficult (1999). Here Wyatt shares Lawrence Dodd's theory of social cleavage according to which, where political parties are organised along social cleavage lines their key motivation will be to look after the interests of their respective constituencies and any effort to find middle ground with an adversarial constituency will be discouraged and difficult to sustain (Dodd 1976).

According to Wyatt, the social structure in Uttar Pradesh is highly stratified, with the SP strongly related to the middle castes and in an adversarial relationship with the upper-caste-dominated Congress Party; the BJP, though drawing support from a more diverse constituency, enjoying much of the support of the upper castes which once supported the Congress Party and the BSP appealing essentially to the middle castes, the same constituency as the SP (Wyatt 1999).

Lefebvre \& Robin (2009) highlight the importance of different geographical bases of support to the composition and sustainability of Indian pre-electoral coalitions. They argue that the BJP-led alliance declined because it had to give too much to access central power because of its concentration in specific geographical areas in contrast to its arch rival, the Indian National Congress, which enjoyed the advantage of having a spatially-scattered voter base which enhanced its alliance bargaining position. The two authors also note that pre-election alliances in India 'are more likely to win elections when their size (in number of parties) is large but characterised by significant size difference between the coalition partners' (Lefebvre \& Robin 2009).

Because of the prevalence of deeply-rooted social cleavages in India, which is also a notable feature in Africa, the experience of the world's largest democracy is rich in lessons for the continent.

\section{BACKGROUND TO PARTY ALLIANCES AND COALITIONS}

Contemporary African political history starts with the Berlin Conference of 1884-1885, which resulted in the subdivision of the African continent into a multiplicity of states based on the economic and geopolitical interests of the participating Western powers of the time. This exercise resulted in the creation of states composed of a diversity of ethnic, racial, religious and linguistic groups. The new states faced the daunting challenge of achieving nation-building, having gone through the often divisive pre-independence elections largely contested by ethnically-based political parties in a process exacerbated by the widespread use of the 'winner-takes-all' electoral system inherited from colonisation. 
Pre-independence political parties were, in essence, formed along ethnic lines (Oyugi 2006), a trend that has continued. In this context, an electoral defeat did not only mean the defeat of a political party but of a whole ethnic group. The resulting post-election resistance to state power by the defeated parties or ethnic group culminated in ethnic polarisation and, in the worst of cases, civil wars and massacres, leaving deep scars in the socio-political fabric of these plural societies.

States had to find ways of dealing with the centrifugal trends in order to achieve some degree of national cohesion. In this context, nation-building became a fundamental objective for nearly all countries in Africa given that it was seen as a certain way of ensuring the peaceful coexistence of the various societal groups. Since political parties were themselves formed along ethnic, linguistic, regional and / or religious lines, several types of political party regulations were attempted to address the ethnic politics that threatened 'social peace, national integrity and political stability' (Bogaards 2008).

After a century of 'divide and rule' by the colonial powers, national cohesion efforts in Africa have often entailed the construction of a national identity through the integration of the various groups into a nation. National cohesion efforts have encompassed a range of initiatives such as the careful choice of national anthems, flags, national days, national languages and national myths; the use of military force; sports events; propaganda; the development of major infrastructure; massive investment; economic growth and revenue redistribution. Other important mechanisms for nation-building include the engineering of particular political systems and institutions, electoral systems, party systems and the devolution of some powers from national to sub-national entities.

In relation to political parties, targeted strategies that were developed and implemented included but were not limited to the establishment of single-party systems (in the former Zaire, Togo, Gabon, Cameroon, Malawi, Zambia, Kenya, Tanzania, Rwanda, Burundi, Congo-Brazzaville and Côte d'Ivoire), the merger of political parties (Zimbabwe) and the imposition of a two-party system as briefly introduced in Nigeria in the mid-1990s. An extreme option has been the banning of all political parties, as in Swaziland, or a one-party system disguised as a noparty system in Uganda, which ended in 2005, or a de facto one-party state such as Eritrea, where the People's Front for Democracy and Justice (PFDJ) rules and no other political groups is allowed to organise.

With the re-introduction of political pluralism in the early 1990s the building of pre-election alliances and post-election coalition governments has emerged as a new trend among political parties, which has allowed them to be more effective in fragmented party systems than they would be on their own. This was the case in Benin, Côte d'Ivoire, the Democratic Republic of Congo (DRC), Ethiopia, Kenya, Malawi and Nigeria. 
Alliances and coalitions have therefore helped parties to access and/or maintain power, limit the majority level of the winning party or coalition and to reach out to parties from across diverse social divides. What is relatively less known is the impact of pre-election alliances and coalitions on party systems, democratic consolidation, state governability and national cohesion. This article makes a contribution to reducing this knowledge gap.

\section{FACTORS MOTIVATING PARTY ALLIANCES AND COALITIONS}

This section answers the question: 'What are the causes and factors motivating alliance and coalition-building, their survival and disintegration?' Party allianceand coalition-building in Africa are unequally influenced by institutional, political, legal, social and financial factors. These factors include the nature of the political regime, the type of electoral system, the legal framework governing political parties and alliances and coalitions, the nature of political parties and the party system, ethno-linguistic and regional factors, financial motivation, ideologies (in rare cases) and classes.

The results of the previous election can have a bearing on which parties are selected and who among the leaders will be the flag bearer. The motives, roles and personality of party coalition leaders also influence alliances. More generally, the inadequate institutionalisation of democracy, the domination of the founding leaders over their parties and the structural and organisational weaknesses or strengths of political parties also affect not only the parties themselves but party alliances and coalitions. In addition, the political economy of the country, especially in the context of limited career opportunities outside of government, often leads to the building of unprincipled coalitions (Kadima 2006b).

\section{The political regime factor}

The type of political regime has an impact on the formation of electoral alliances and coalition governments. In a parliamentary regime (Mauritius, South Africa and Lesotho), the government's survival depends on the confidence of Parliament. As a result, partners work hard to maintain the cohesion of the governing party or coalition. The main difference between Mauritius and Lesotho, on the one hand, and South Africa, on the other, is that the latter has a dominant-party system in which the African National Congress (ANC)'s electoral victory has been a foregone conclusion from one election to the next.

Between the first democratic elections, in 1994, and the second, in 1999, there was a constitutional requirement that South Africa must be governed by a coalition. As a result, during those years the country was run by a government 
of national unity which featured National Party and Inkatha Freedom Party (IFP) Cabinet ministers alongside those of the victorious ANC. Since 1999, however, the ANC has had the overwhelming majority of seats in the National Assembly and there has been no need for it to enter into an alliance or coalition to remain in power. However, it has continued to invite representatives of smaller parties to take on Cabinet positions in the predominantly ANC Cabinet, pointing to another motivation for building coalitions - to maintain or extend political consensus across ideological and social divisions. In addition, in areas where the ANC is not dominant (at sub-national levels, particularly municipal councils), the party has been forced to enter into alliances with smaller parties in order to govern.

Presidential regimes in ethnically divided countries (Kenya and the DRC) depend on their alliance partners to be elected. Once in office, this dependency ends as presidents use their constitutionally entrenched prerogatives to govern rather than subjecting themselves to pre-election agreements signed with alliance partners. Nonetheless, the president and his/her party would necessarily need the support of their partners to enable the smooth passage of legislation (Altman 2000). The deep factionalism in the presidential coalitions in Malawi led to an extreme situation involving a failed attempt to impeach the president, the resignation of the president from the party that sponsored him in the presidential elections and floor crossing by dozens of MPs to the new presidential party (Kadima \& Lembani 2006). Similarly, in Kenya, President Mwai Kibaki's refusal to honour the pre-election agreement and the memorandum of understanding of the National Rainbow Coalition (NARC) compelled some of his alliance partners to stop cooperating with him, accusing him of having violated his commitment. The impasse within the governing alliance made Parliament almost ungovernable for most of the five-year term of the NARC (Kadima \& Owuor 2006). The president began to rely on the opposition, including the Kenya African National Union, which had, until then, led the opposition to NARC, in an attempt to pass legislation.

Party coalitions in parliamentary regimes tend to be more effective than those in presidential regimes as, for the survival of government, consensus must be sought. In presidential regimes elected heads of state tend to overlook coalition agreements, giving precedence to their constitutional prerogatives. This situation has often resulted in division within the coalition, compromising the functioning and effectiveness of Parliament and government. This is even more the case when coalition partners opt to use Parliament as a platform from which to fight each other, which could lead, as in the case of Kenya between 2003 and 2007 , to a fractured parliamentary caucus engaged in internecine squabbling and unable to pass crucial legislation (Kadima 2006b). The flipside is that an effective coalition can lead to greater accountability in Parliament and curb excessive use of the presidential prerogative. 


\section{The electoral system factor}

Different kinds of electoral systems give rise to different types of instrumental calculations among political parties. The nature and character of the electoral system also predetermines the natural propensity of parties to opt for coalitions or alliances.

In socially-divided African countries which use the first-past-the-post (FPTP) electoral system and are not dominant-party systems, political parties generally choose to enter into pre-election alliances in order to avoid wasting votes. This is often done by pooling votes in support of a candidate of one of the alliance parties. By coming together they increase their chances of winning the elections. In Kenya the requirement that presidential candidates must obtain a minimum of $25 \%$ of the votes cast in each of more than half of the country's 47 counties reinforces the need for parties to coalesce prior to the elections. Mauritius's three-way FPTP, where voters are each given three ballots, combined with the geographical concentration of the various communal groups in rural and urban areas, requires pragmatism. Thus party leaders have adopted a broad-based ethnic approach and enter into pre-election alliances in order to ensure electoral victory.

In African countries using proportional (PR) electoral systems where there is no election threshold which might result in wasted votes, political parties do not rush into pre-election alliances. Instead they build post-election coalitions on the basis of the number of seats each partner party has won. This was the basis of the post-election provincial coalitions between the ANC and the IFP from 1994 to 2004 in KwaZulu-Natal (KZN); the Democratic Party (DP) and the New National Party (NNP) in 1999 in the Western Cape and the ANC and the NNP in 2003 in the Western Cape.

In the past Mozambique also used a PR system for its parliamentary elections, with a minimum electoral threshold of $5 \%$ of the national vote, making it vital for small parties to build pre-election alliances in order to avoid wasting their votes. This explains why ten small political parties that failed to win a single parliamentary seat in 1994 entered into pre-election alliances with the Resistência Nacional de Moçambique (RENAMO) in both the 1999 and the 2004 parliamentary elections (Kadima \& Matsimbe 2006). This electoral threshold was subsequently scrapped. Consequently, no significant coalition was built for the 2009 legislative elections in Mozambique.

South Africa's local government elections are conducted under a pure mixed system, with $50 \%$ of seats fought on the basis of FPTP and the other $50 \%$ according to a PR closed party list. In this case, the FPTP element means parties stand a better chance of having a particular candidate elected if they enter into pre-election alliances. This was clearly the case in the 2000 local government elections when a pre-election alliance among the DP, NNP and the Federal Alliance (FA) ensured 
their victory in the Cape Town Metro council and several other local councils (Kadima 2006d).

The use of a two-round electoral system for legislative elections also encourages the building of pre-election alliances. This happens in the first round and, more importantly, ahead of a run-off election, as has been the case in Mali and the Central African Republic.

In instances where there is a constitutional requirement that a candidate standing in a presidential election must secure a $50 \%+1$ majority of valid votes in the first round and no candidate achieves this majority a run-off is organised between the two top candidates. In these instances pre-election alliances tend to be formed ahead of presidential elections. African presidential regimes provide an interesting opportunity for the study of alliance and coalition politics and a study of countries like Senegal, Mali, Guinea, the DRC (before 2011 when the two-round system was replaced with a simple majority), Benin, Côte d'Ivoire Kenya and Madagascar would yield interesting insights

\section{Legal framework governing alliances and coalitions}

Political parties and their alliances and coalitions are generally affected either by the absence or the inadequacies of legislation. In Malawi the legal framework does not explicitly recognise party coalitions. As a result, alliances and coalitions have no status beyond that of gentlemen's agreements. The consequence of this inadequate recognition of coalitions is that in Malawi the position of head of state is unduly strengthened at the expense of alliance and coalition partners. Partner parties are weakened by the fact that they find themselves campaigning for their joint presidential candidate, promoting his / her party's symbol. At the same time, they campaign for their own parties in the parliamentary elections, using their own party's symbol, a practice that confuses voters and negatively affects the chances of parliamentary candidates representing coalition partners that do not field a presidential candidate (Kadima \& Lembani 2006).

The fact that until recently Kenyan law did not recognise party alliances and coalitions forced the NARC and subsequent alliances to register as political parties in their own right. The legal framework governing Kenya's political parties was amended in 2011. Section 10 of the Political Parties Act (PPA) of 2011 provides that

two or more political parties may form a coalition before or after an election and shall deposit the coalition agreement with the Registrar. A coalition agreement entered into before an election shall be deposited with the Registrar at least three months before that election. A coalition agreement entered into after an election shall be 
deposited with the Registrar within twenty-one days of the signing of the coalition agreement. A coalition agreement shall set out the matters specified in the Third Schedule.

In Mauritius any group of parties wishing to contest an election together must register with the Office of the Electoral Commissioner. The alliance is also required to have its symbols registered with the electoral commissioner. The recognition of party alliances helps prevent the unfairness experienced in Malawi and, until 2011, in Kenya.

The floor-crossing legislation in South Africa, enacted to facilitate the formal disintegration of a party alliance, made it possible for members of Parliament who were elected under the closed list proportional representation system to quit their parties, form new parties, or join other parties, without losing their seats in the National Assembly or the provincial legislatures (Booysen 2011). This legislation led to the periodic splitting of parties, defections of elected party representatives and, ultimately, to the fragmentation and weakening of the party system (Kadima 2008). In addition, floor crossing undermined the meaning of representative democracy as elected leaders joined parties that stood for views other than those for which their parties were elected. Floor crossing was hugely unpopular in South Africa and was scrapped after it had served the purpose of enabling the ANC to control, albeit temporarily, the Western Cape (Kadima \& Booysen 2009).

This article does not advocate the over-regulation of party alliances and coalitions. It recognises that the inadequate or silent nature of the legislation has made party alliances and coalitions dysfunctional in many countries and, in extreme cases, has led to fracture, instability, tensions and violence, as it did in Kenya between 2003 and 2008.

\section{Ethno-linguistic and regional factors}

It must be recognised that politics in Africa is still characterised by ethno-linguistic and regional factors. All the major parties, both ruling and opposition, in Kenya, Malawi, Mauritius, Mozambique and South Africa are associated with a particular ethnic, racial, linguistic, religious or regional group. Certain party alliances and coalitions end up resembling alliances and coalitions of tribes and sometimes multipartyism turns into multitribalism. As a result, the ethnic dynamics that have an adverse impact on individual political parties often find their way into the alliances and coalitions. The successive coming together of the main party leaders in Kenya was, in fact, the coming together of the main ethnic groups in support of the party alliances (Kadima \& Owuor 2006). 
The case of Mauritius, one of very few countries on the continent with a long tradition of multiparty government, is unique, owing to social cleavages which characterise the society, the parliamentary system and the multiparty system, in which the two dominant political parties cannot command an absolute majority on their own. Any party that is serious about winning an election must therefore enter into a pre-election alliance. Since independence in 1968 Mauritius has never been governed by one single party.

Mauritius, characterised by racial and religious cleavages as well as welldelineated social classes and class consciousness, had held nine successful general elections up to 2010, of which all but one were contested by two major pre-election alliances. Ethnic calculation has been central to these elections in which, essentially, an incumbent coalition has been challenged by an opposition alliance (Sithanen 2003; Kadima \& Kasenally 2005). Furthermore, in Mauritius, politicians often 'sell' coalitions as the only means of accommodating ethnic diversity, building consensus and promoting social cohesion. The reality is, however, different, as coalition-building and, ultimately, its breakdown, takes place along ethnic lines and these coalitions are essentially a vehicle that allows politicians to access or maintain power. In other words, the raison d'être of a party coalition is ultimately to govern, and ethnic accommodation, though desirable and reassuring, has essentially been of peripheral importance.

In order to guarantee its electoral victory the Mouvement Militant Mauritian (MMM) entered in coalition with a smaller party, the Mouvement Socialiste Mauritian (MSM), in 2000 and agreed to share the post of prime minister, with the MSM taking the first three years, while the MMM contented itself with the remaining two years. This ethnic calculation was based on the recognition of the demographic weight of the Hindu majority, who constitute about half the population (Kadima \& Kasenally 2005). It can, however, be argued that even though ethnic accommodation was only a by-product of alliance and coalition building, it is nonetheless an essential derivative.

In Malawi from 1994 to 2004 the northern-region-based Alliance for Democracy (AFORD) was able to oppose the southern-region-based United Democratic Front (UDF) against the central-region-based Malawi Congress Party (MCP) (Kadima \& Lembani 2006), which allowed it to play the role of kingmaker by making and unmaking coalitions, until its own disintegration into smaller parties.

Ironically, the attempt to attract as many ethnic groups as possible in order to be seen as politically correct and win elections results in a lack of homogeneity which constitutes the main weakness of any coalition in an ethnically diverse society. In other words, the diversity that allows a coalition to win an election is, paradoxically, the factor that is likely to cause it to disintegrate. 


\section{The ideology factor}

Ideology has not been an essential factor in party coalition-building or splitting in African countries. In Malawi (Kadima \& Lembani 2006) and Kenya, interviews with leaders of the main parties showed that representatives were unsure about their party's ideology. Even when there were some rudiments of ideology, parties did not live up to it and none of their coalition-related decisions seemed to be clearly based on ideological considerations. As for Mozambique, while it is relatively discernible that RENAMO is a centre-right party and its longstanding rival, the governing Frente de Libertação de Moçambique (FRELIMO) a centreleft party, the ten smaller parties which coalesced around RENAMO from 1999 to 2009 under the RENAMO União Eleitoral (RENAMO UE) did not all have a clearly professed ideology. Similarly, in many other African countries such as Senegal, the DRC and Mali, ideology has no bearing at all on the building or collapse of party alliances and coalitions, the single most important motivation being the quest for public office.

In Mauritius and South Africa, however, the main political parties can be classified with some more certainty on a left-right spectrum, though a superficial observation of coalition politics in these countries might lead to the impression that there is a virtual absence of ideology. Both Mauritius and South Africa are exportoriented and find themselves under the influence of economic neo-liberalism (Narsiah 2006; Lallah 2000). This has, through pragmatism, pushed the main political parties in these countries to the centre of the ideological continuum, with slight nuances regarding the role and place of the state in the economy.

In the same vein, since the end of the Cold War, most African political parties have realigned themselves ideologically, moving to the centre. The challenges facing African countries are huge and well known. They include extreme poverty levels, economic competitiveness and the need to improve the quality of education and access to health. Most parties have largely espoused economic liberalism, with the state playing an important role in order to accelerate socio-economic development and alleviate poverty. It is therefore not surprising that there has been a convergence of the main ideas and priorities, thus creating a degree of connection among the parties. Such a context justifies the reduction of the importance of ideology as a differentiating factor in alliance and coalition building.

\section{The financial security factor}

Undoubtedly, parties enter into coalitions in order to win elections. Access to power often comes with various privileges, including financial advantages. 
Affiliated parties benefit from a coalition by winning parliamentary seats and, where possible, ministerial and other well remunerated posts. In other words, coalitions provide financial security for members of the coalition partners. In addition, in those countries that have an FPTP electoral system it tends to be an advantage to run for office as an incumbent.

Incumbency gives easier and often undue access to public resources such as state-owned media, civil servants, vehicles, the state apparatus and even public funding, which serves to perpetuate certain individuals and parties in office, thereby limiting economic gains to a self-circulating and incumbent elite. Interestingly, while financial security is often associated with ruling parties or coalitions, the opposition RENAMO in Mozambique was able to offer the same to its partners, essentially through their parliamentary seats and public funding of parliamentary parties.

The Mozambican case explains, to a large extent, the unusual longevity of its opposition alliance. In the same way, in decentralised systems such as South Africa and, since 2013, in Kenya, the national opposition parties can win executive positions at sub-national levels (eg, governor or mayor) and be the governing parties, thus enjoying the advantage of incumbency in the entities under their control.

This situation has improved the sustainability of opposition coalitions in these countries. Arriola (2013) further developed this aspect of the study of coalition by arguing that lack of finances means opposition alliances often do not form, hence ruling parties find it easier to build coalitions than their opponents.

\section{Other factors}

Other factors, such as the personality and ambition of party leaders and competition among them, deep differences between alliance and coalition partners, the results of the previous elections, the proximity of a general election, inadequate internal democracy and transparency and poor management procedures all influence pre-electoral alliances and post-election coalitions (see Kadima 2006b).

\section{CONSEQUENCES OF ALLIANCES AND COALITIONS FOR THE POLITICAL, DEMOCRATIC AND PARTY SYSTEMS}

This section answers the following questions: how effective have electoral alliances and coalition governments been in fostering national cohesion in socially-divided African countries? What has been the impact of party alliances and coalitions on party systems in Africa? 


\section{Effects on national cohesion}

The arbitrary subdivision of the African continent in 1885 has led to the creation of states where violent ethnic, linguistic, regional and / or religious cleavages have made peaceful coexistence and national cohesion challenging and one important objective of immediate pre-independence and post-independence party coalitions was to bring about national unity and nation-building. The fact that alliances and coalitions have brought together political parties from different and even conflicting ethnic, regional, religious and linguistic backgrounds has helped to foster a degree of national cohesion, particularly in ethnically-divided African countries.

In Mauritius, after the pre-independence elections of 1967, the Labour Party (LP) and its then arch rival, the Parti Mauricien Socialiste Démocrate (PMSD), formed a post-election coalition which lasted for 15 years, thus helping nationbuilding by reconciling the Hindu majority, represented by the LP, and the socalled General Population, which consists mainly of people of African descent and those of mixed races, represented by the PMSD (Kadima \& Kasenally 2005).

In South Africa the 1994-1996 government of national unity, consisting of the ANC, the National Party (NP) and the IFP, also contributed to nation-building in the racially and ethnically divided country. This transitional constitutionallyenshrined multiparty government arrangement brought together the architects of apartheid, the NP, and the party chiefly responsible for apartheid's destruction, the ANC.

One of the most successful party coalitions in the post-apartheid era in South Africa has, surprisingly, been the successive post-election coalitions between the ANC and the IFP in the KwaZulu-Natal province from 1994 to 2004 and nationally. The ANC and IFP came together in an attempt to eradicate political violence in $\mathrm{KZN}$ and their coalition contributed to restoring peace in the volatile province after decades of hostility between supporters of the two parties.

Party politics in Kenya are ethnically based. Correspondingly, inter-party politics are ethnically driven. By bringing together ethnic groups from opposing sides, political party alliances and coalitions have contributed to reinforcing national cohesion, as illustrated by the nationwide enthusiasm generated by the formation of the NARC. Coalitions have also allowed for a more equitable sharing of national resources. It can also be observed that grand coalitions like NARC (2002) and the PNU-ODM (2008-2013), while they can annihilate opposition and restrict accountability, have contributed to national cohesion because they are about the politics of inclusion, while smaller governing coalitions make sections of the population feel that they are under-represented in state institutions. The formation of electoral alliances tends to ensure rapprochement among various 
ethnic groups, however, the emergence in Kenya of two main alliances competing for power has meant that the country has often found itself politically polarised, with the rivalry leading to grave violence and loss of life.

The establishment and disintegration of party alliances has undeniably affected individual political parties both positively and negatively. Some effects are tangible, while others are mere perceptions which must be validated by means of further research.

The building of party alliances and coalitions has improved the image of some regionally-based political parties, giving them a degree of national relevance. In Malawi, for instance, through its intermittent alliances with the southern- regionbased UDF and the central-region-based MCP, the northern-based AFORD raised its profile and became a national role player (Kadima \& Lembani 2006). The same applies in South Africa to the IFP, which, thanks to its participation in the ANCled national government, changed its widely perceived image as a provincial party essentially concerned with the interests of its Zulu constituents to that of a national player. The participation of its president, Mangosuthu Buthelezi, in government as minister of home affairs and his periodic appointment as acting president of the Republic also enhanced his stature (Kadima 2006d).

In substance it can be observed that party alliances and coalitions do contribute to a degree of national cohesion just as their collapse may lead to political polarisation, which can undo the progress achieved in nation cohesion.

\section{Effect on party systems}

This section deals with the impact of party alliances and coalitions on party systems in Africa. The establishment and disintegration of party alliances and coalitions undeniably affects political parties both individually and collectively. The argument here is that pre-electoral alliances and coalition governments often result in the strengthening of the main political party at the expense of its junior partners. This can be illustrated with the example of South Africa, where, although there were short-term benefits in coalition building for individual political parties (eg, positions in state institutions) there were also adverse effects resulting both from entering a coalition and from subsequently withdrawing from it. One such example is that of the NNP, which joined the DP in 1999 to form the Democratic Alliance (DA), only to be progressively 'swallowed' by its partner. Its withdrawal from the coalition and the subsequent formation of a second one - this time with the ANC - angered the majority of its supporters. Ultimately, it was coalition politics that led to the demise of the NNP when its supporters were shared among the DA, the ANC and the Independent Democrats (ID). 
Similarly, a study commissioned by the Freedom Front Plus (FF+) showed that its 1994 cooperative arrangement with the ANC was punished by its supporters in the 1999 general elections, when the party lost more than $50 \%$ of its seats in the National Assembly. It has also been argued that the DA's Coalition for Change with the IFP and its consequent support for the maintenance of Ulundi as the provincial capital of KZN resulted in lost votes in Pietermaritzburg and surrounding areas in the 2004 provincial election in favour of the ANC, which had expressed a preference for keeping Pietermaritzburg as the provincial capital.

There is also a perception that the decade-long participation of the IFP in a coalition government with the ANC in KZN and nationally might have confused IFP supporters. The steady decline in support for the IFP in KZN since 1999 and the increase in support for the ANC has been interpreted by some in the IFP as the party's supporters preferring to vote for the governing party rather than for its junior partner. In the same vein, the alliance between the DA, which is the main opposition party in South Africa, with the ID, a smaller opposition party, ended in the integration of the ID into the DA.

Also in South Africa, the ANC entered into coalition cooperative arrangements with a range of smaller and widely different political parties, including the IFP, the NNP, the United Democratic Movement, the Minority Front, the Azanian People's Organisation, the FF+ and the ID. This openness enhanced the governing party's image as a moderate dominant party at a time when the country needed to work hard to reduce ethnic and racial polarisation (Kadima 2006d) and allowed the smaller parties a policy- and decision-making role they might otherwise have been unable to access. The DA, too, entered an alliance with the NNP and a coalition with the IFP, the UDM and the ID. In virtually all these cases, the ANC and the DA, which have been the senior partners, have seen their partners lose ground, which has, at times, resulted in the integration of junior partners such as the NNP and the ID or their gradual reduction in the next elections.

A more general consequence of the rise and fall of various party coalitions in South Africa is that parties have learnt their lesson and have become exceedingly cautious, resulting in far fewer alliances and coalitions built, with a greater preference for situational issue-based cooperation and alliances over specific campaigns, for example, opposition to the Protection of State Information Bill or the tolling of freeways in Gauteng.

In Malawi, too, coalition politics has led to the demise of some parties. By entering into a coalition with the UDF prior to the 2004 elections and, more importantly, because of its support for the UDF leader's controversial attempt to extend his term of office beyond the constitutional maximum of two fiveyear terms, AFORD not only lost members through defections, it was severely sanctioned by the voters. Its parliamentary representation shrank from 29 seats 
in 1999 to six in 2004. In 2009 this support dropped to a mere one seat (Kadima \& Lembani 2006).

In Mauritius it has been argued that the MSM paid for its leader's submissive attitude to its coalition partner, the MMM. The fact that the MSM leader lost his parliamentary seat in the July 2005 general elections was interpreted as the consequence of this alliance.

Coalitions have also had the effect of fragmenting the party system in some countries. It has been observed in Mauritius and Malawi that politicians have often left their parties to form new ones in order to join the governing party as a coalition partner. In the following general elections those splinter parties have tended to disappear.

South Africa, although its party system is relatively stable, has also experienced fragmentation, though as a result of the opportunistic introduction of the floor-crossing legislation for a short period rather than as a consequence of party coalitions per se.

Equally, in Kenya, small parties were weakened by coalitions, especially when their leaders were in government and tended to neglect their parties in favour of the coalition. Such leaders frequently paid the price for their absence during the subsequent elections. It has been observed in some instances that the stronger the coalition the weaker the affiliate parties, and vice-versa.

The experiments of African countries with party alliances and coalitions show that smaller political parties usually enter into coalitions for short-term goals like jobs or to have a single issue addressed, while larger parties tend to focus on a long-term strategy aimed at consolidating their support base. As a result, party alliances and coalitions tend to disproportionately weaken small parties while strengthening the main party in the alliance or coalition. It would not be unrealistic to expect this process to culminate in the long run in the gradual reconfiguration and stabilisation of the party system with the consolidation of the large party and a reduction in the number of smaller parties

Perhaps an exception to this rule is Mauritius, where the third-largest party, the MSM, seems to have understood how party alliances weaken junior partners and was able to maintain itself in power by taking advantage of the strong rivalry between the two main parties, the Labour Party (LP) and the Mauritian Militant Movement (MMM). The MSM's Anerood Jugnauth managed, for 13 consecutive years, to occupy the position of prime minister, a period that ended only when the LP and MMM formed an alliance in 1995. However, thanks to a new coalition with the MMM, Jugnauth made a comeback in 2000 and led the country for a further three years as prime minister before he was elected by Parliament as non-executive president of the Republic (Kadima \& Kasenally 2005). The MSM has remained the third force in the country as the two main parties have never been able to 'swallow' it. 
In Kenya smaller parties have also realised that when a coalition is strong its affiliate parties tend to be weaker. Conversely, when affiliate parties are strong, the coalition tends to be weaker (the Party of National Unity). On the other hand, it has been noted that coalition leaders tend to be the main beneficiaries of the coalition (Kibaki in NARC, Odinga in the ODM and Kenyatta in Jubilee) and would prefer a centralised and even integrated coalition structure for better control of and discipline within the coalition. Junior coalition partners, on the other hand, favour a decentralised structure in order to keep their bargaining power and flexibility. This quest for independence by party leaders has resulted in a fragmented, unstable and weaker party system in Kenya. The laws relating to political parties provide for substantial funding of parties that have secured a minimum of $5 \%$ of the total vote. It is expected that this provision will encourage parties to reconsider the value of remaining in loose alliances and coalitions and building viable political parties instead.

\section{CONCLUSION}

Most African societies are ethnically divided and the majority of African political parties are ethnically and / or regionally based, while the patrimonial nature of African politics not only turns political competition into ethnic competition, it also turns it into economic rivalry. An election defeat often feels like the political and economic defeat of an entire ethnic group. In this context, the building of alliances and coalitions is largely seen as an appropriate democratic way of accommodating ethnic diversity. By bringing together and accommodating political parties from different, if not conflicting, political, ethno-linguistic and regional divides, party alliances and coalitions have contributed to fostering a stronger sense of national cohesion.

On the other hand, the disintegration of party coalitions when they take place in a context of strong enmity between the competing alliances and coalitions may provoke politically-motivated ethnic violence and lead to a reversal of some of the progress made in building national cohesion. It can, however, be argued that, in the long run, election alliances and coalitions may ameliorate the intensity of strife when party leaders come to realise that they have a chance of being elected in peaceful and democratic elections by entering into pre-election alliances or through post-election coalitions.

This study has observed that pre-election alliances and post-election coalitions have become the rule of the democratic game in a sizeable number of African countries and are increasingly seen by citizens as a democratic mechanism for accessing or retaining power. This relative public support for alliances and coalitions is inconsistent with most legal frameworks governing party alliances 
and coalitions in Africa which make it possible for the senior partner party to take undue advantage of its junior partners to the detriment of the whole party system.

Multiparty democracy rests on strong, viable and effective political parties and party coalitions, where applicable, as well as on stable party systems. Where legal frameworks weaken the party system, including alliances and coalitions, reform may be necessary. Because alliances and coalitions are institutions of public interest the law should provide for some regulation and require that their objectives, duration and agreement be made public. The electoral commission or another appropriate body could be given the power to decide whether the coalition agreement or memorandum of understanding complies with the law.

In 2011 Kenya reformed its political party laws along the lines of the recommendations by Kadima \& Owour (2006). It is too early to assess what improvements these reforms will bring. It is, however, worth pointing out that extreme regulation of coalitions should be avoided as it could lead to the infringement of freedom of association. The right balance should, therefore, be struck in the interest of the stabilisation of African party systems and national cohesion.

\section{- REFERENCES}

Altman, D. 2000. 'The Politics of Coalition Formation and Survival in Multiparty Presidential Democracies: The Case of Uruguay 1989-1999'. Party Politics 63. Arriola, L R. 2013. Multiethnic Coalitions in Africa: Business Financing of Opposition Election Campaigns. Cambridge: Cambridge University Press.

Axelrod, R. 1970. Conflict of Interest: A Theory of Divergent Goals with Applications to Politics. Chicago, IL: Markham.

Baron, D. 1993. 'Government Formation and Endogenous Parties'. American Political Science Review 87(1), March.

Baron, D. 1998. 'Comparative Dynamics of Parliamentary Governments'. American Political Science Review 92.

Bogaards, M. 2008. 'Comparative Strategies of Political Party Regulation'. In B Reilly \& P Nordlund (eds). Political Party Regulations in Conflict-Prone Societies: Regulation, Engineering and Democratic Development. Tokyo: United Nations University Press

Booysen, S. 2011. The African National Congress ANC and the Regeneration of Political Power. Johannesburg: Witwatersrand University Press.

Dalton, R \& M Wattenberg. 1993. 'The Not So Simply Act of Voting'. In A Finifter (ed). The State of the Discipline, $2^{\text {nd }}$ edition. Washington: American Political Science Association.

De Swaan, A. 1973. Coalition Theories in Cabinet Formations. Amsterdam: Elsevier. 
Dodd, L. 1976. Coalitions in Parliamentary Governments. Princeton: Princeton University Press.

Franklin, M. 1985. The Decline of Class Voting in Britain. New York: Oxford University Press.

Franklin, M. 1992. 'The Decline of Cleavage Politics'. In M Franklin, T Mackie \& H Valen (ed). Electoral Change. New York: Cambridge University Press.

Gamson, W. 1961. 'A Theory of Coalition Formation'. American Sociological Review 26(3), June.

Hamilton, R. 1972. Class and Politics in the United States. New York: Wiley.

Kadima, D. 2003. 'Political Party Coalition Building and Splitting in Post-Apartheid South Africa: Effects on Representative Democracy and Party System'. Paper presented at the Electoral Institute of Southern Africa EISA Roundtable on 'Political Party Coalitions: Strengthening Democracy through Party Coalition Building', Cape Town

Kadima, D (ed). 2006a. The Politics of Party Coalitions in Africa. Johannesburg: Konrad Adenauer Stiftung and EISA.

Kadima, D. 2006b. 'African Party Alliances: Comparisons, Conclusions and Lessons'. In D Kadima (ed). The Politics of Party Coalitions in Africa. Johannesburg: Konrad Adenauer Stiftung and EISA.

Kadima, D. 2006c. 'The Study of Party Coalitions in Africa: Importance, Scope, Theory and Research Methodology'. In D Kadima (ed). The Politics of Party Coalitions in Africa. Johannesburg: Konrad Adenauer Stiftung and EISA.

Kadima, D. 2006d. 'Party Coalitions in Post-Apartheid South Africa and their Impact on National Cohesion and Ideological Rapprochement'. In D Kadima (ed). The Politics of Party Coalitions in Africa. Johannesburg: Konrad Adenauer Stiftung and EISA.

Kadima, D. 2008. ‘Party Regulations, Nation-Building and Dominant Party Systems in Southern and East Africa'. In B Reilly \& P Nordlund. Political Party Regulations in Conflict-Prone Societies: Regulation, Engineering and Democratic Development. Tokyo: United Nations University Press

Kadima, D \& S Booysen (eds). 2009. Compendium of Elections in Southern Africa 19892009: 20 Years of Multiparty Democracy'. Johannesburg: EISA Publications.

Kadima, D \& R Kasenally. 2006. 'The Formation, Collapse and Revival of Political Party Coalitions in Mauritius: Ethnic Logic and Calculation at Play'. In D Kadima (ed). The Politics of Party Coalitions in Africa. Johannesburg: Konrad Adenauer Stiftung and EISA.

Kadima, D \& S Lembani. 2006. 'Making, Unmaking and Remaking Political Party Coalitions in Malawi: Explaining the Prevalence of Office-Seeking Behaviour'. In D Kadima (ed). The Politics of Party Coalitions in Africa. Johannesburg: Konrad Adenauer Stiftung and EISA. 
Kadima, D \& Z Matsimbe. 2006. ‘RENAMO União Eleitoral: Understanding the Longevity and Challenges of an Opposition Party Coalition in Mozambique'. In D Kadima (ed). The Politics of Party Coalitions in Africa. Johannesburg: Konrad Adenauer Stiftung and EISA.

Kadima, D \& F Owuor. 2006. 'The National Rainbow Coalition: Achievements and Challenges of Building and Sustaining a Broad-Based Political Party Coalition in Kenya'. In D Kadima (ed). The Politics of Party Coalitions in Africa. Johannesburg: Konrad Adenauer Stiftung and EISA.

Kapa, M A. 2008. 'The Politics of Coalition Formation and Democracy in Lesotho'. Politikon 35(3).

Karume, S. 2003. 'Conceptual Understanding of Political Coalitions in South Africa: an Integration of Concepts and Practices'. Paper presented at the Electoral Institute of Southern Africa EISA Roundtable on 'Political Party Coalitions: Strengthening Democracy through Party Coalition Building', Cape Town

Lallah, R. 2000. 'Ile Maurice: Les femmes à la pointe du combat'. In FMI, les peuples entrent en résistance. Geneva : CETIM, Geneva. Available at: www.cetim.ch/ oldsite/pub/00amau2.htm

Lawrence, D. 1996. The Collapse of the Democratic Majority. Boulder, CO: Westview Press.

Lefebvre, B \& C Robin. 2009. 'Pre-electoral Coalitions, Party System and Electoral Geography: A Decade of General Elections in India 1999-2009'. South Asia Multidisciplinary Academic Journal, Special Issue 3, 'Contests in Context: Indian Elections'. Available at: samaj.revues.org/index2795.html

Leiserson, M. 1968. 'Factions and Coalitions in One-Party Japan: An Interpretation Based on the Theory of Games'. American Political Science Review 62.

Luebbert, G M. 1983. 'Coalition Theory and Government Formation in Multiparty Democracies'. Comparative Politics 15(2), January.

Manza, J \& C Brooks. 2003. Social Cleavages and Political Change: Voter Alignment and US Party Coalitions. Oxford: Oxford University Press.

Osaghae, E. 1999. 'Democracy and National Cohesion in Multiethnic African States: Nigeria and South Africa Compared'. Nations and Nationalism 5(2).

OUTA. 'Why we oppose e-tolling of Gauteng's Freeway upgrade'. Available at: www.outa.co.za/site/about-outa/why-we-oppose-e-tolling/\#sthash. dc0WFcaQ.dpuf

Oyugi, W. 2006. 'Coalition Politics and Coalition Governments in Africa'. Journal of Contemporary African Studies 24(1).

Protection of State Information Bill. Available at: www.info.gov.za/view/ DownloadFileAction?id=118894

Resnick, D. 2011. 'Do Electoral Coalitions Facilitate Democratic Consolidation in Africa?' Helsinki: United Nations University-World Institute for Development Economics Research UNU-WIDER. 
Riker, W. 1962. The Theory of Political Coalitions. New Haven: Yale University Press. Star, The. 2013. 'Cosatu will oppose what is unjust,' 12 November. Available at: www.iol.co.za/the-star/ cosatu-will-oppose-what-is-unjust-1.1605928\# . UoJJoOJ0YcQ

Narsiah, S. 2006. 'Neoliberalism and privatisation in South Africa'. GeoJournal 052002, 57(1-2)

Sithanen, R. 2003. 'Coalition Politics under the Tropics: Office Seekers, Nation Building: A Case Study of Mauritius'. Paper presented at the Electoral Institute of Southern Africa EISA Roundtable on 'Political Party Coalitions: Strengthening Democracy through Party Coalition Building', Cape Town

Warwick, P. 1994. Government Survival in Parliamentary Democracies. New York: Cambridge University Press.

Wyatt, A. 1999. 'The Limitations on Coalition Politics in India: the Case of Electoral Alliances in Uttar Pradesh'. Commonwealth \& Comparative Politics 37(2). 